\title{
Business Model Experimentation for the Circular Economy: Definition and Approaches
}

\author{
Nancy M. P. Bocken ${ }^{1,2}$ (D) $\cdot$ Ilka Weissbrod ${ }^{3} \cdot$ Maria Antikainen $^{4}$ \\ Received: 3 March 2021 / Accepted: 8 March 2021 / Published online: 26 April 2021 \\ (C) The Author(s) 2021
}

\begin{abstract}
Business model experimentation has been identified as a key driver for business competitiveness but is underexplored in the sustainability and circular economy spheres. What is business model experimentation for the circular economy? This study follows a two-step approach: a literature analysis followed by a qualitative practitioner study. Based on these, circular business model experimentation is defined as an iterative approach to develop and test circular value propositions in a real-life context with customers and stakeholders, starting with a shared goal. It involves rapid learning based on empirical data to provide evidence on the viability of circular value propositions. Iterations involve increased complexity of experiments. There is a learning focus on initiating wider transitions, such as transforming consumer behaviours for the circular economy. We visualise the emerging research landscape, including research streams from business, transitions, engineering, and design. Practically, we illuminate how practitioners view the concept and current experimentation tools and approaches.
\end{abstract}

Keywords Sustainability $\cdot$ Circular business model $\cdot$ Sustainable business model $\cdot$ Sustainable business model experiment - Circular economy transition · Circular business model experiment

\section{Introduction}

The circular economy concept has been adopted by business as a powerful paradigm to address increasing sustainability issues $[1,2]$. The circular economy focuses on slowing,

Nancy M. P. Bocken

nancy.bocken@maastrichtuniversity.nl

1 Maastricht Sustainability Institute, School of Business and Economics, Maastricht University, Tapijn 11 Building D, P.O. Box 616, 6200 Maastricht, MD, Netherlands

2 Lund University, IIIEE, Tegnérsplatsen 4, 22350 Lund, Sweden

3 Leuphana University of Lüneburg, CSM, Universitätsallee 1, 21335 Lüneburg, Germany

4 VTT Technical Research Centre of Finland, Tekniikankatu 1, 33101 Tampere, Finland 
closing, narrowing, and regenerating resource loops to address pressing issues around manmade climate change, biodiversity, and resource strains [3-5]. Large established businesses are vocal about the potential of circular business models to save resources while safeguarding future competitiveness [6], but the operationalization of the circular economy in practice is lagging behind [7-9], and sustainability outcomes of innovating business models are uncertain [10]. Echoing the work by Blomsma and Brennan [11], Baldassarre et al. [12], and Kirchherr et al. [2], we argue that the circular economy concept is in need for action and validation. Experimentation is needed not only to trial the viability of options in a business context but also to initiate transitions within existing companies.

This research investigates the emerging concept of business model experimentation within the circular economy, and tools, methods, and approaches, based on literature analysis and a practice study to provide novel insight into this emerging and necessary research agenda. Below, we set out the four reasons for this study: (1) the pressing need to address climate and resource issues and role of business, (2) the interest in experimentation in sustainability and circular economy research and practice, (3) the tradition of experimentation in field of transitions studies and recent recognition of the business model as a source of inertia, and (4) the popularity of the experimentation concept and its divergent applications in business studies.

First, due to the increased resource and climate pressures [13, 14], companies face the need for changing the way they do business dramatically. The circular economy is a potential avenue for change which has received significant business interest [6], which has translated into company commitments to the circular economy transition (e.g. [15]). However, knowledge and methods on how to transition to a circular economy from a business perspective are only emerging [7, 16, 17], despite a long tradition of sustainability research and the role of business (e.g. $[18,19])$. More clarity in this emerging research field of the circular economy and future research directions are needed, building on knowledge in different disciplines.

Second, while business model experimentation is helpful to test the marketplace acceptance of new products and services [20], in the field of sustainability, experimentation can also ensure positive impacts on society and the environment [21]. It has been identified as an emerging theme in newer circular business research (e.g. [22]) and practice [23, 24]. Experimentation can kick-start transitions in business by demonstrating the potential of circular business models in practice and starting the internal change processes [17] but also wider industry and societal transitions towards a circular economy, where the dominant linear business model is seen as a key barrier $[8,25]$.

Third, as asserted by Fischer and Pascucci [8] and Sarasini and Linder [25], experimentation has long been featured in transitions research, where experiments help to challenge the dominant institutions and economic paradigms of society [26, 27]. It has been described as a potential approach for accelerating sustainable innovations in transitions literature (e.g. [21, 28]). Moreover, in transitions research, dominant unsustainable business models (e.g. the linear take-make-dispose model) have recently been described as inertia in sustainability transitions [25]. Besides transitions research, experimentation is a core concept in engineering, economics, natural sciences, and the medical sciences [29, 30], with different meanings, which suggests the need for more conceptual clarity.

Finally, business model experimentation is addressed as an important concept in mainstream business literature [31-33]. Business model innovation requires significant trial and error and ongoing business model adaptation [20]. Hence, it comes to no surprise that experimentation has been increasingly adopted in business practice [30, 34]. Experimentation 
with new business models has been linked to popular tools and approaches. These include the Business Model Canvas [35], a visual representation of a business model; the Lean Startup, an approach focused on building, measuring and learning through a structured innovation process [36]; and effectuation, which is about 'using available knowledge, means, and resources within iterative business innovation processes' ([12] p. 2, based on [37, 38]). While experimentation has been described as an approach to business model innovation (e.g. [31, 39]), it is also a research method within management research (e.g. [40]). Hence, in the business studies context, experimentation has multiple interpretations.

This study explores the role of business model experimentation and its opportunities for accelerating and facilitating the implementation of circular business models in companies. It seeks to answer the question and sub-questions:

What is circular business model experimentation (CBME)?

- How can CBME be defined?

- What are the main characteristics of CBME?

- What are the literature streams that underpin CBME?

- What tools and methods may be used for CBME?

Next, the two-step method is explained in more detail, followed by the results with focus on the evolving landscape and research streams, definition, tools, and methods as well as the practitioner perspective. Finally, contributions to research and practice are presented.

\section{Method}

This research method is twofold. The first step is the literature analysis to investigate the emerging research landscape. The second step is an empirical investigation among practitioners involved in business model experimentation for the circular economy.

\section{Step 1: Literature Analysis}

Table 1 summarizes the steps of the literature analysis, which consisted of two stages.

Table 1 Literature review ${ }^{1}$ details

\begin{tabular}{lll}
\hline Stage & Details & $\begin{array}{l}\text { Number of } \\
\text { studies }\end{array}$ \\
\hline $1 \quad \begin{array}{l}\text { Systematic database search for journal articles with search string in Web of Science, } \\
\text { Scopus, and Google scholar (search string: 'business model' AND 'experiment*' }\end{array}$ & 20 \\
AND 'circular economy') after removing duplicates & 17 \\
& Number of papers after applying inclusion and exclusion criteria & 122 \\
& Systematic database search for journal articles with search string in Web of Science, \\
Scopus, and Google scholar (search string: 'business model' AND 'experiment*' & \\
AND 'sustainability') after removing duplicates & 22 \\
Number of papers after applying inclusion and exclusion criteria & 17 \\
Total number of circular business model experimentation papers & 22 \\
Total number of sustainable business model experimentation papers & 39 \\
Total number of papers analysed &
\end{tabular}

${ }^{1}$ The literature search was completed at the end of September 2020 
To establish the theoretical grounding, we examined literature on business model experimentation for the circular economy or, in short, circular business model experimentation (CBME) in stage one. The following search string was used to systematically review article titles, abstracts, and keywords: 'business model' AND 'experiment*' AND 'circular economy' (results in Table 1). Web of Science, Scopus, and Google Scholar databases were selected to review literature written in English. These databases are complementary for management research purposes and the search focused on management, engineering, and social sciences. Solely journal articles were included. Books, conference papers, and book chapters were excluded because the rigour of the academic peer review of these sources varies greatly. The abstracts were examined to identify the initial literature sample. Inclusion criteria were as follows: The studies must be about business model experiments, the circular economy concept, and have a business focus. Studies were excluded if they formed no or a negligible part of the theoretical underpinning or research contribution (Appendix A Table 4 shows the included literature).

In the second stage of the literature analysis, we explored sustainability-oriented business model experimentation (SBME) because sustainable business model research pre-dates the newer circular economy concept [5]. Moreover, the search for CBME papers generated a limited number of papers. The search string for stage two was 'business model' AND 'experiment* AND 'sustainability'. The same selection criteria and databases were applied as in the initial literature search (Appendix B Table 5 shows the included literature).

Finally, the identified studies were investigated in detail to develop a comprehensive definition. This development was based on characteristics of CBME uncovered from the articles, the identified tools and approaches for CBME, and the dominant research streams.

\section{Step 2: Empirical Analysis-Understanding of CBME Among Practitioners}

The empirical analysis consisted of querying practitioners in the area CBME. The aim was to illuminate how CBME involved in practice view the topic and whether this differs from the analysed literature. The following single question was asked: 'What does "circular business model experimentation" mean to you?' Sampling consisted of identifying practitioners with recent experience in the field of circular business model experimentation, whether this was in a guiding, implementing, or funding role. Respondents consisted of international group of practitioners in the direct network of the authors, who were contacted via email or phone, and the group was further expanded by looking for relevant expertise in the authors' networks through the LinkedIn network. While 34 practitioners were contacted, a total of 30 respondents were included in the analysis. There were four non-responses: two due to indirect contact (the query being forwarded), one due to long-term leave, and one with outdated contact details. Appendix $\mathrm{C}$ Table 6 includes an overview of the respondents, covering multiple types of companies and sectors (e.g. fashion, banking, retail) and roles (e.g. innovation consultant, sustainability manager, venture leader, director innovation, and sustainability).

\section{Results}

The results are split in the outcomes of Step 1 (literature analysis) followed by Step 2 (insights from practitioners) and the overall analysis of both analyses. The results of Step 1 start with an overview of the publications followed by definitions and 
characteristics, literature streams, and tools and methods, in line with the sub-questions. Step 2 focuses on validating the definitions and characteristics of CBME based on the practitioner study.

\section{Step 1: Overview of Publications}

The literature search led to a total number 17 core journal papers on circular business model experimentation (Appendix A Table 4) plus 22 additional papers to understand the broader sustainable business model experimentation field that pre-dated the circular business model experimentation concept (Appendix B Table 5). The review confirmed that this is an emerging research field as all publications were dated between 2011 and 2020. In the circular economy selection, all except two papers [41, 42] included empirical work, predominantly based on cases. The sustainability selection included only one conceptual paper [43]. Whereas in the older SBME work, fewer tools and processes were developed (4 out of 22 publications), in the newer CBME, 8 out of the 17 publications included a tool or process. This suggests that the circular economy concept lends itself for practical implementation. Furthermore, the empirical work through cases, workshops, and direct experiments with business and other organisations demonstrates the practical focus of the circular economy.

The literature search also identified diverse business contexts, e.g. grassroots organizations [44], startup [45], social businesses [46], and large established businesses [22]. Some of the longstanding and ongoing areas of research in this review focus on (electric) mobility (e.g. [47, 48]) and solar PV in different contexts (e.g. [49]), suggesting that these might be sectors where experimentation is becoming more commonplace and where business model innovations are gaining traction. Other pockets of research relate to business experimentation in city contexts [47, 50, 51], buildings [52, 53], clothing (e.g. $[22,54])$, and farming $[44,55,56]$. Rather specialized, washing machines were represented with three papers $[16,57,58]$. Sector-specific studies included online education [59], university campuses [60], travel [61], water filtration [62], electric motors [58], and fastmoving consumer goods [63]. Areas of technical innovation include Internet of Things (IoT) [16], smart grids [47], smart cities [50], and smart collection [51], suggesting the need to experiment at the intersection of technology and business models (see also [20, 64]).

Finally, different types of circular business models are addressed. For example, Danso et al. [55] and Yazan et al. [56] refer to closing the loop through 'creating value from waste' in biological resource cycles, and Xue et al. [51] investigate recycling and smart collection. Others highlight slowing the loop: Bashir et al. [63] look at refill and reuse; Lieder et al. [57] compare buy-back, leasing, and pay-per-use; Weissbrod and Bocken [22] refer to slowing the loop for fashion; and Torrieri et al. [53] refer to repurposing monastery buildings as a way of direct reuse. Most papers have an environmental focus, whereas Täuscher and Abdelkafi [59] also consider the economic viability of the business model, and Dobson et al. [61] integrate social aspects. Specifically, the payper-use business model [65] seems to be popular and is addressed in Lieder et al. [57], Sousa-Zomer et al. [62], and [16, 66]). Service models in general, like mobility as a service (e.g. [48, 67]), are popular, which is not surprising as this is one of the more established research fields in the sustainable and circular business model sphere (e.g. [65, 68]). 


\section{Defining and Characterising Circular Business Model Experimentation}

The literature review results confirm the lack of conceptual clarity on circular business model experimentation. Table 2 shows different literature assertions identified on SBME and CBME.

The literature offers no unifying definition on CBME, but there are clear common characteristics of the concept. We identified ten key characteristics based on analysing dominant characteristics among the articles (Appendix A Table 4):

Table 2 Literature descriptions on business model experimentation

Source $\quad$ Descriptions of CBME

Guldmann and Huulgaard, [69] 'the complex nature of the [CBME] process is best dealt with via internal and external experimentation $[\ldots]$ and through this experimentation, the company can explore different possibilities for value creation, delivery and recapture and for offering customers an extended value proposition'

Konietzko et al. [70]

'circular business model experimentation can help stimulate innovation and action towards circularity in organizations. It has the potential to promote an iterative 'getting things done' attitude among the participants [...] experiments are situated between fast learning (e.g., paper sketches, interviews) and slow learning (e.g., business plans, pilots, market studies)'

Fleischmann [60]

'Circular Economy lends itself to the use of design-led innovation methods (...) Design-led innovation offers methods to drive radical innovation and business model transformation based on customer-centricity' (p. 384). '[It] involves rapid prototype testing and using a co-creation experience process because it is impossible to understand the whole ecosystem upfront' (p. 388)

Sousa-Zomer et al. [62]

'Business experimentation is essential for sustainable business model implementation'

Source

Aagaard et al. [45]

Descriptions of SBME

'[We define] six types, namely network business experimentation, selling business experimentation through trial and error, technology scope business experimentation, specialist business experimentation, customer-driven business experimentation, and sustainable value-driven business

experimentation, are used by all of our case companies and as a continuum. [...] [L]earning is an inherent role of experimentation'

Bashir et al. [63]

'[Business experimentation for sustainability] can enable companies' transition from an existing business model to a new and more sustainable business model. This requires a reiterative approach to design, experimentation and analysis that can generate actionable insights on barriers for the adoption of such solutions, and interventions to overcome them'

Dobson et al. [61]

'[B]usiness model experimentation involves actively learning about the environment and incorporating new information and feedback to refine the initial proposition into a viable business model. At the core of this experimentation and exploration is organizational learning'

'[B]uilding upon the knowledge accumulated from incorporating feedback from repeated successive experiments improves an organizations experiential knowledge and in turn, reduces the uncertainty of operating in a new environment (...) when the results of an experiment are negative, the business model will be adjusted and another experiment will begin'

Ortega et al. [46]

'Rather than spend an inordinate amount of time and resources on planning what is inherently unknown and uncertain, [organizations] quickly map out their assumptions and then run experiments to test those assumptions. They can then adjust their plans based on what they have learned from their experiments'

Huijben and Verbong [71]

'Business model experiments can take place both within and between firms. By performing business model experiments new business opportunities can be found or even created'

Note. Newest publications on top 


\section{Designing and testing new circular value propositions}

The aim of experimentation is to test propositions (product/service offerings) with customers or other stakeholders to test their viability from a customer perspective and circular economy perspective.

2. Testing in a real-life context, with stakeholders

Tangible evidence is needed to create evidence to convince stakeholders inside and outside the business about the viability of new propositions. Testing takes place with customers and other stakeholders.

\section{Generating and analysing empirical data}

Data are generated and analysed, e.g. through experimentation as a research method or using methods such as Lean Startup [36].

\section{Iteration and rapid learning}

Iteration and rapid learning are recognised in practitioner work (e.g. [24, 35]), and this was referred to in several studies.

\section{Exploration and creating options}

Experimentation is about finding out what works under which conditions and identifying and creating options, in the transition from a linear to a circular economy.

6. Reducing uncertainty, risk, and cost

Experimentation helps to reduce uncertainty and associated risk and cost.

\section{Overcoming organizational inertia (in large established firms)}

Organizational inertia hinders circular business model innovation in large established firms, and experimentation can help large firms overcome these.

8. Vision and purpose and/or goals

Through experimentation, companies work towards a shared vision and goal.

\section{Partnering with others}

This involves collaboration with others whether these are businesses, (local) governments, nongovernmental organizations (NGOs), or citizens.

\section{Contribution to a wider transition}

The aim is to contribute to a wider transition towards the circular economy and sustainable development.

Nine out of the 17 articles covered all ten criteria, and a further five at least $70 \%$ of all criteria (Appendix A Table 4). Criteria 8 and 9 on a shared vision and partnering with others were missing in some of the studies anchored in engineering, namely, the studies by Yazan et al. [56] which included modelling and computational experiments of the biogas supply chain and Marconi et al. [58] on a model for effective disassembly times for home appliances.

\section{Literature Steams for Circular Business Model Experimentation: an Evolving Landscape}

The literature review identified diverging, yet complimentary perspectives on the concept of circular business model experimentation (Fig. 1, Appendix D Table 7). Figure 1 illustrates how the reviewed literature in this article has evolved since 2011 - as this is the date when the first articles explicitly at the intersection of experimentation in a business and sustainability context appeared to have emerged. For example, some authors used the Business Model Canvas in a sustainability context (e.g. [44, 71]), whereas others evolved the canvas (e.g. [12]) or referred to the Lean Startup (e.g. [46]). While most studies described business experiments as an 


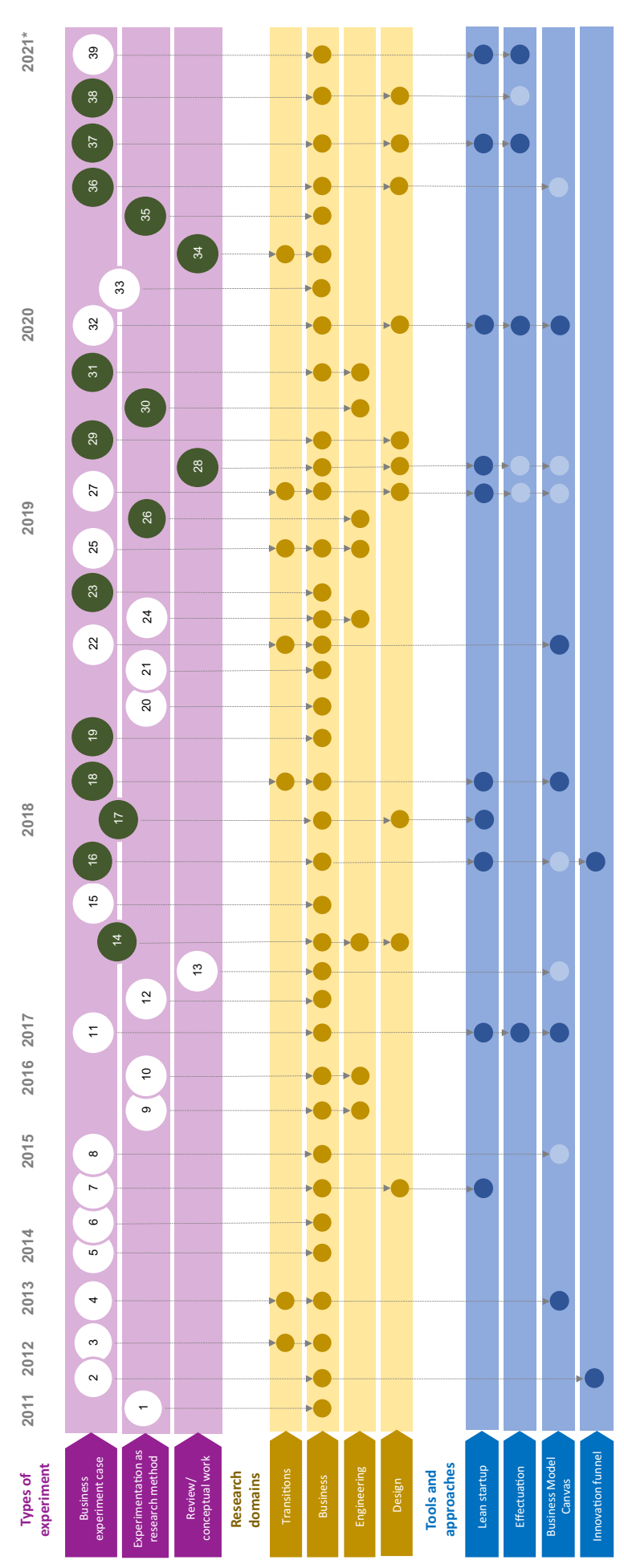

$\Xi \dot{9}$

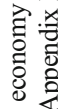

흘 옹

궁

式

च

롤

䒽

牙颁

छ

记.

를

乙.

这

卷 额

节

范

흉

$\Xi$

点 $\Xi \frac{0}{\pi}$

\&

马.

을

. ․ㅠ

可 可

क्

. ํํㅇ

의요

远

$\mp .50$

के है

용

要

w芯

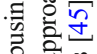

हैं

휼 무

흔 능 웅

० :

离 $\cong \frac{\square}{4}$

है

등

ब

bo 긍

कo

步

군

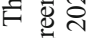

它若离 
innovation activity in companies (e.g. [72, 73]), some studies use experimentation as a research method (e.g. [48, 75]) similar to the earliest work identified [49]. Three studies use both business experimentation as an innovation case and experimentation as a research method [16, 57, 63]. Four dominant research streams emerged from the literature review: literature anchored in business studies, engineering studies, transitions research, and design. Nearly half of the studies (18 out of 37) took a multidisciplinary perspective. Seven studies took a transitions' and a business perspective, but only three studies integrated three disciplines. The different streams will be discussed next.

Literature Anchored in Business Studies The first set of articles are the ones anchored in business studies ( 37 out of 39 papers), mostly include business experiments as an innovation case, followed by experiments as a research method, and three conceptual papers.

Studies typically used the term experimentation in a rather lose fashion, not applying strict 'scientific rules' as recommended in work on experimentation as a research method [40]. Only Bashir et al. [63] and Yoon et al. [75] used a control group, as typical element of design of experiments as perused in the natural sciences. Aspects like randomization and a control group are typically not referred to; however, in Bocken et al. [16], the lack of a control group is described as a limitation. The literature review results are aligned with the comparison of the experimentation approach in the natural sciences and the corporate experimentation process by Weissbrod [30], who describes that control groups are not part to the experimentation process for sustainable innovation due to the complexity of sustainable innovation processes. Thus, most identified literature sources use the term experiment, when in fact 'quasi experiments' are described [40]. This means that the term experimentation is used when referring to approaches or processes that lack critical aspects of a 'real experiment'. It has been argued that a scientific approach to innovation can be beneficial to the success of innovations in organizations, especially through the formulation and testing of hypotheses during establishing new organizations [79]. The question, however, remains to what extent aspects of experimental designs, more common in natural and physical sciences, would apply within the business context and to what extent this is even desirable [29]. For example, some of the reviewed papers [12] use a more effectual approach building on 'what is available' [38], which seems to contrast the more structured Lean Startup approach, although other cases started off with using the Lean Startup, but ended up taking a more effectual approach [54].

Using experimentation as an approach to innovation, some articles used an action-oriented research approach with a variation of techniques [12, 44, 54, 69]. Bocken et al. [54] draw on Ries' [36] and Blank's [80] interpretations of an experimental learning approach. This approach consists of formulating hypotheses, gathering data to test these, and developing conclusions based on the gathered data over a limited time period [36]. Guldmann and Huulgaard [69] use the interactions with companies to formulate barriers to circular business model innovation. Ramos-Mejía and Balanzo [44] used a mix of qualitative methods (interviews, focus groups, direct observation, and ethnographic work) within a socio-technical experiment to understand how grassroots ecopreneurs developed sustainable business models in Colombia. Baldassarre et al. [12] used qualitative and action research techniques, coupled with design science research, to support sustainable startups in prototyping while developing a tool to develop future startups with sustainable business model innovation. Finally, recent 
work used a straightforward survey as choice experiment to test food provisioning practices in CBMs [78] or thought experiments to generate insights on future circular business models [41].

Literature Anchored in Design The most popular intersection between disciplines lies between design and business studies: Ten studies combine these perspectives (Fig. 1). Studies at the intersection of design thinking, business model innovation, and experimentation already started with the work by Ortega et al. [46], who were experimenting with social impact innovation. Yet with three studies at the start of 2020, it appears that this is a new and popular research area. Guldmann and Huulgaard [69] regard experimentations as a solid part of circular business model innovation, making a distinction of internal and external experimentations (e.g. testing a prototype together with a supplier). Baldassarre et al. [12] tackle the challenge they refer to as the 'design-implementation gap' and design an organizational tool (SBM Pilot Canvas) to plan and execute small-scale pilots for implementing sustainable business models. Konietzko et al. [67] propose a set of principles for circular ecosystem innovation in which experimentation plays one part. Thus, from the viewpoint of the crossroads of design thinking for business model innovation and experimentation, relevant themes for further research include the following: frameworks and processes for innovation and implementation of business models, which is also naturally interconnected with the area of practical tool and method development $[66,81]$.

Literature Anchored in Engineering Studies Eight studies are anchored in engineering studies (Fig. 1). Most papers in the field of engineering studies (except Xue et al. [51] and Torrieri et al. [53]) used experiments as a method.

Different types of experimental methods are used. Lieder et al. [57] used a simulation model to run an optimization experiment to find the most cost-effective combination of reused, remanufactured, and recycled components for a business model for a washing machine manufacturer; Torrieri et al. [53] developed an evaluation model based on multicriteria analysis and a financial model to support the choice of an alternative reuse of an ancient monastery in Italy. Their approach, similar to the tool in Lieder et al. [57], is suggested as a future decision support tool (Torrieri et al. [53]). Täuscher and Abdelkafi ([59], p. 654) developed a simulation based on the 'learning sector' by running a simulation for Coursera.

Other researchers developed knowledge more generally to inform business model development for future decision-makers. Yoon et al. [75] calculated the willingness to pay for solar lanterns in India and found that this is low, despite a trial period and postponed payment to increase sales. Kendel and Lazaric [50] installed smart meters in consumers' homes with a control group. In addition to monitoring in this experiment, questionnaires were used. The findings suggest that any interventions that motivate households to change their energy habits would help, which would have implications for future business model development [50]. Xue et al. [51] also used qualitative research with an open questionnaire and interviews to assess intelligent collection companies. They show the potential for integration of the informal waste collection into the more formal intelligent collection companies using internet and communication technologies [51]. Marconi et al. [58] developed a method based on datamining to develop disassembly planning for a washing machine and coffee machine. Yazan et al. [56] developed an enterprise input-output approach to model physical and monetary flows of the manure- 


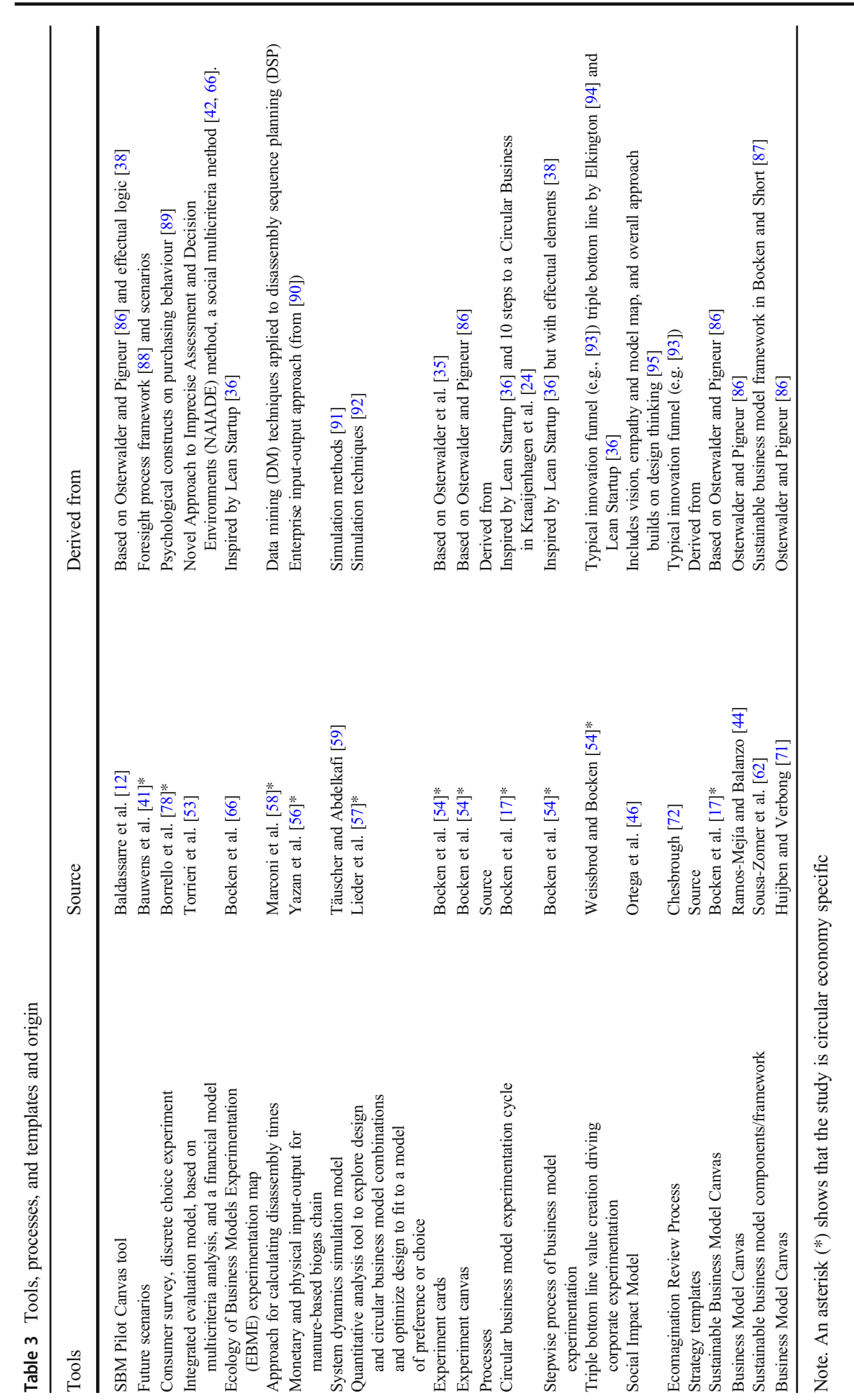


based biogas supply chain. Computational experiments highlighted under which conditions; cooperation is beneficial for all actors [56].

Literature Anchored in Transitions Studies Seven studies combine a business with a transitions research perspective (Fig. 1). Huijben and Verbong [71] describe business model innovation in relation to a transition to solar photovoltaics (PV) as part of a wider renewable energy transition, citing Geels [82, 83] on transitions and Geels and Raven [84] on niche developments in transitions. Jolly et al. [73] refer to the work by Kemp et al. [26] on niche developments in their study on business model experiments for off-grid PV solar energy in India. Ramos-Mejía and Balanzo [44] refer to the work by Kemp et al. [26] and Smith and Raven [85] on niches in transitions to sustainability in their work on grassroots ecopreneurs. Xue et al. [51] do not specifically cite the transitions literature stream but rather refer to the need for wider economic transitions processes in China. Bauwens et al. [41] refer to the transition to the circular economy and the potential of scenarios to inform strategies and policies.

Multidisciplinary Perspectives The 'most multidisciplinary' studies are the three studies by Lieder et al. [57], Xue et al. [51], and Bocken et al. [66] (Fig. 1). Lieder et al. [57] position themselves in both business and engineering studies but also bring in knowledge from design thinking in their study on future business models for washing machine manufacturing. Similarly, Xue et al. [51] take a business and engineering perspective but also bring in the wider transitions' lens for sectorial transformation in China. Bocken et al. [66] make the connection between business models and transitions research, but also design thinking when supporting the 'design' of a new pay-per-use business model. The CBME field is diverse in itself, and recent studies also draw on multiple disciplines simultaneously.

\section{Tools and Approaches for Circular Business Model Experimentation}

Different tools and processes for circular business model experimentation have been developed. Table 3 provides the overview of tools and processes.

The articles show close ties to the existing practitioner tools such as the Business Model Canvas and Lean Startup method (see also, [34]). Ramos-Mejía and Balanzo [44] and Huijben and Verbong [71] both use the Business Model Canvas as part of their studies. Others like Baldassarre et al. [12] and Bocken et al. [17] adapt the Business Model Canvas for sustainability or circularity purposes. Chesbrough [20] in his work on business model experimentation already mentioned potential approaches to experimentation, including a more structured Lean Startup style approach using hypothesis testing [36], versus a more emergent effectual approach to business model experimentation, focused on 'what is available' [38]. Some articles identify this more effectual approach in addition to the more structured Lean Startup being adopted by business (e.g. [12, 54]), but the dominant sources for inspiration appear to be the Lean Startup, as well as the Business Model Canvas by Osterwalder and Pigneur [86]. Chesbrough [20] also notes the importance of an iterative approach, in line with design thinking, which is also being adopted in some articles (e.g. [12, 46, 57, 69]). Some articles also build on more traditional new product development innovation funnels (e.g. [22, 72]). 
In studies in the engineering research stream, decision support tools have been developed, such as the work by Marconi et al. [58] that calculates disassembly times in a future circular economy and the model by Yazan et al. [56] to assess the potential for collaboration. Torrieri et al. ([53]) use multicriteria analysis to support the decision on redevelopment of a monastery. Lieder et al. [57] and Täuscher and Abdelkafi [59] use forms of simulation to support future business model development.

Recent work embeds insight from psychology to understand possible consumer behaviour shifts [78] and insights from scenario analysis to develop circular economy pathways [41].

\section{Step 2: the Practitioner Study}

The practitioner study was conducted to investigate how the CBME field emerged compared to literature. Thirty practitioners answered the question: 'What does "circular business model experimentation" mean to you?'

Appendix C Table 6 shows the coded version of the responses by the practitioners against the criteria in Section 3.1.2 to identify similarities and differences. Two out of the thirty practitioners referred to all ten criteria from our definition in Section 3.1.2. This small number is not surprising as we asked for the practitioners' viewpoints and not a comprehensive definition. Some points were more prominent in the practitioner responses than in the reviewed studies. In particular, the practitioner data sample showed an emphasis on the customer, using and balancing metrics, systemic change, and scaling up. The focus on the customer and balancing financial, with societal and environmental metrics was expected, seeing the business context of the respondents. The focus on scaling up and systemic change is, however, noteworthy as it shows that the CBME concept is seen as a lever for change by practitioners.

Two out of the thirty practitioners with a science background mentioned a controlled lab type of experimentation environment, although most referred to the rather practical setting of experimentation in collaboration with customers, suppliers, and other stakeholders. As for tools and methods, the Lean Startup approach was named once. One participant, however, mentioned 'build-test-learn', and three others refer to hypotheses testing. Design thinking was mentioned once.

\section{Characteristics and Definition}

While the literature analysis gave comprehensive insights, the practitioner study gave enriched perspectives to the CBME perspective. These related to the customer and transforming consumer behaviour, using and balancing metrics, systemic change, and scaling up. Based on the practitioner perspectives, we evolved the original $10 \mathrm{CBME}$ characteristics (new in italics):

1. Designing and testing new circular value propositions. The aim of experimentation is to trial propositions (product/service offerings) with customers and other stakeholders to test their viability from a customer perspective, circular economy, and systemic perspective.

2. Testing in a real-life context, with stakeholders. Tangible evidence is needed to create evidence to convince stakeholders inside and outside the business about 
the viability of new propositions. Testing takes place with customers and other stakeholders.

3. Generating and analysing empirical data. Data are generated and analysed, e.g. through experimentation as a research method or using methods such as Lean Startup.

4. Iteration, rapid learning, and moving from experiment to scaling. The process is iterative (e.g. build-measure-learn) and the complexity of experiments build up over time, towards scaling up from a small-scale towards expansion within and across markets.

5. Exploration and creating options. Experimentation is about finding out what works under which conditions and identifying and creating options, in the transition from a linear to a circular economy.

6. Developing the business case while balancing societal and environmental impact. Experimentation helps to reduce uncertainty and associated risk and cost about future propositions, but various criteria (e.g. business case, circularity, sustainability) need to be balanced during the experimentation process.

7. Overcoming organizational inertia (in large established firms). Organizational inertia hinders circular business model innovation in large established firms, and experimentation can help large firms overcome these.

8. Vision and purpose and/or goals. Through experimentation, companies work towards a (shared) vision and goal.

9. Partnering with others. This involves collaboration with others whether these are businesses, (local) governments, NGOs, or citizens.

10. Contribution to a wider transition. The aim is to contribute to a wider transition towards the circular economy and transforming consumer behaviours.

Based on these ten characteristics, we assert that CBME is

An iterative approach to develop and test circular value propositions in a real-life context with customers and stakeholders, starting with a shared goal. It involves rapid learning based on empirical data to provide evidence on the viability of circular value propositions. Iterations involve increased complexity of experiments. There is a learning focus on initiating wider transitions, such as transforming consumer behaviours for the circular economy.

\section{Discussion}

This study investigated the research question of 'What is business model experimentation for the circular economy?' through a structured literature review followed by a practitioner study. Here, we discuss the implications for research and practice.

\section{Implications for Future Research}

We conceptualise CBME as an interdisciplinary and actionable concept, with studies anchored in the domains of business, transitions, engineering, and design thinking and various articles crossing research domains. With the rise of the circular economy concept, and the need for 
companies to transform their business models, we see ample opportunity for further research. For example, the intersections of CBME with transitions studies [25] and design thinking (e.g. $[12,60])$ are only starting points for further tool and method development. This may specifically include service design (e.g. $[96,97])$ to support the understanding of how circular business models perform in practice through highlighting customer touchpoints and painpoints, or gamification (e.g. [98]), and find new opportunities to stimulate sustainable behaviour. Insight from psychology might further the understanding of consumer behaviour transformation (e.g. [63]). From the field of transitions studies, techniques around scenarios and strategic foresight might support ideation for transformative circular business model concepts (e.g. [41]). Further afield research fields such as biology applied to business ecosystems [66] and the broader concept of Industrial Ecology [99],might also inspire further tool and method development.

Second, methodologically, this research uncovered the need for future research to determine (1) the level of control in experimentation, (2) the merits of qualitative versus quantitative evidence, and (3) the customer centric approach versus sustainability as diver of experimentation. First, the level of control in business experiments is still an area for debate. The literature on experimental methods in management research (e.g. [100]) suggests the need for a 'scientific approach', including the development of hypotheses, and preferably a form of randomization and a control group. However, it appears rarely possible to set up a fully controlled experiment within a business context [22], and most of the identified studies lack experimentation aspects such as a control group, and only two practitioners referred to a 'lab style' experimentation approach. Second, while the Lean Startup approach to business experimentation emphasizes quantitative evidence (e.g. number of clicks on an advert), qualitative data may also provide a richer view on customer segments and aspects of the offering that appeal to them [101]. Kendel and Lazaric [50], for example, combined quantitative with qualitative data. Indeed, interviews and focus groups are also part of the wider experimentation 'toolkit' used in businesses [35]. We see a discrepancy in how experimentation is proposed by Ries [36], Blank [64, 80], and Osterwalder et al. [35] who recommend a customer-driven approach and the studies with focus on circularity and sustainability. For the customer perspective, insights from marketing and psychology (e.g. [78]) may be embedded in CBME. Bridging divergent perspectives, the sustainable business model tool by Baldassarre et al. [12] integrated aspects of desirability, feasibility, viability, and sustainability. The need to integrate heterogonous metrics also echoes practitioners' views who seek to balance these aspects during experimentation. This could be an area for future research.

Third, the literature on CBME features various tools and methods. Lean Startup and the Business Model Canvas were important influences for several reviewed articles. The Business Model Canvas is sometimes used without an indicated adaptation for sustainability (e.g. [71]) while others propose sustainability variations of the Business Model Canvas (e.g., [17]). Problematically, although Business Model Canvas-type frameworks seem to be useful to identify the different elements of the business model, these frameworks do not directly guide experimentation [34]. Effectuation [38] was mentioned in conjunction with the Lean Startup approach and was a source of inspiration to advance the circular business model experimentation process $[12,54]$. In line with older work [72], structured approaches to innovating (e.g. the stage-gate process; [93]) were featured. In an established company, the structured approach (e.g. [22]) is expected, but the 
emergent more effectual approach typically used by entrepreneurs and as described by Sarasvathy [38] was also found in established business [54]. Further research should investigate which tools are best suited for which organizational context, how to address the difficult question of how to embed sustainability and circularity effectively in the business model, measure impact and balance heterogeneous metrics, and scale up from experiments. Possible theoretical directions relate to the process oriented; dynamic and emergent view of business model innovation should build on the discussions in 'mainstream' business literature (e.g. [102]), in the interdisciplinary sustainability literature (e.g. [25, 81]), and in sustainability-focused literature in management journals (e.g. [103]). The understanding of 'what is an experiment' as a method may help improve the rigour of experimentation.

\section{Implications for Future Practice}

Experimentation has been recognized as a key capability in established companies [104], but few custom-made tools and approaches seem to be developed for this purpose [34], in particular for sustainability or circular economy [105]. Blank [80], Ries [36, 106], and Chesbrough [20] recognize that startups and established corporations need to experiment with the value proposition at the heart of their business model to forge a product/service fit with the marketspace. Whereas startups are an ongoing experiment $[64,80]$, in of established companies, experimentation is needed for long-term firm survival by challenging the dominant business model [104].

This work contributes to practice by highlighting the tools and practices, organizational contexts, and practitioners' views on CBME. The tools and approaches in Table 3 are a starting point for practitioners seeking inspiration for CBME. Identified studies used and derived existing tools (e.g. Lean Startup, Business Model Canvas). Recent work also included choice experiments and scenarios, integrating notions from psychology [78] and transitions studies [41]. Engineering techniques such as simulations are a way to experiment and predict without customer involvement, as a step before necessary user interaction as heralded by studies anchored in design thinking (e.g. [12]).

Finally, practitioners' views on CBME highlighted the need to balance sustainability impact and the business case while experimenting. CBME was viewed as a way to transform consumer behaviour, scale up smaller initiatives, and initiate wider ecosystem transitions. Experiments would build up in complexity and result in larger pilots and scale ups. These points of attention and the 10 characteristics of CBME give practitioners insight into the scope of the emerging topic of CBME.

\section{Limitations}

The literature analysis was limited to peer-reviewed journal papers, studies in the English language, and uses of the specific keyword 'experimentation' in the business context. The practitioner study largely included European practitioners, and for the benefit of the practitioners' time, we focused on one core question. In addition to the directions highlighted above, future work could give insight into the ways of business experimentation in different national, cultural, and sectorial contexts. Moreover, collaborative experimentation practices of business with other societal actors (e.g. NGOs, governments) could be a source for further in-depth research. Furthermore, the highly energy intensive and polluting but non-consumer facing 
industries, such as steel and aluminium, paper, cement, plastics, and mining [13], were not identified in the sample. Research may focus on how such industries can reinvent their business models through experimentation, because of their size and impact. Finally, the circular economy has been critiqued for its predominant environmental and economic focus [5], so the societal pillar (e.g. [40]) could be a source for further research.

\section{Conclusions}

This research studied the novel concept of circular business model experimentation (CBME) to help advance research and practice towards the circular economy based on literature analysis and a practitioner study. The contributions are threefold. First, we define and position CBME as a truly interdisciplinary and emerging concept in the domains of business, transitions, engineering, and design thinking, with potential for more interdisciplinary developments. We define CBME as follows:

An iterative approach to develop and test circular value propositions in a real-life context with customers and stakeholders, starting with a shared goal. It involves rapid learning based on empirical data to provide evidence on the viability of circular value propositions. Iterations involve increased complexity of experiments. There is a learning focus on initiating wider transitions, such as transforming consumer behaviours for the circular economy.

Second, we highlight potential methodological directions based on our research, related to the level of control in CBME, the use of quantitative and qualitative evidence, as well as the need to balance a customer centric with a sustainability-oriented approach. Third, we provide insight into the tools and approaches and their origins as a potential avenue to operationalise the circular economy concept in business through experimentation.

CBME has potential as a transformative concept to support the role of business towards implementing the circular economy approach. Further learning is needed between business studies, design and engineering, and sustainability sciences. This will be challenging and requires deeper investigation, since the impacts of experiments will change in a scaled circular business model over time. Future research should bridge the gap between research and practice for CBME to become a lever for change towards sustainability transitions.

Availability of Data and Material Not applicable.

Code Availability Not applicable.

Funding This project has received funding from the European Union's Horizon 2020's European research Council (ERC) funding scheme under grant agreement no. 850159.

\section{Declarations}

Competing Interests Not applicable.

Abbreviations $C B M E$, Circular business model experimentation; $S B M E$, Sustainability-oriented business model experimentation; $N G O s$, Nongovernmental organizations 


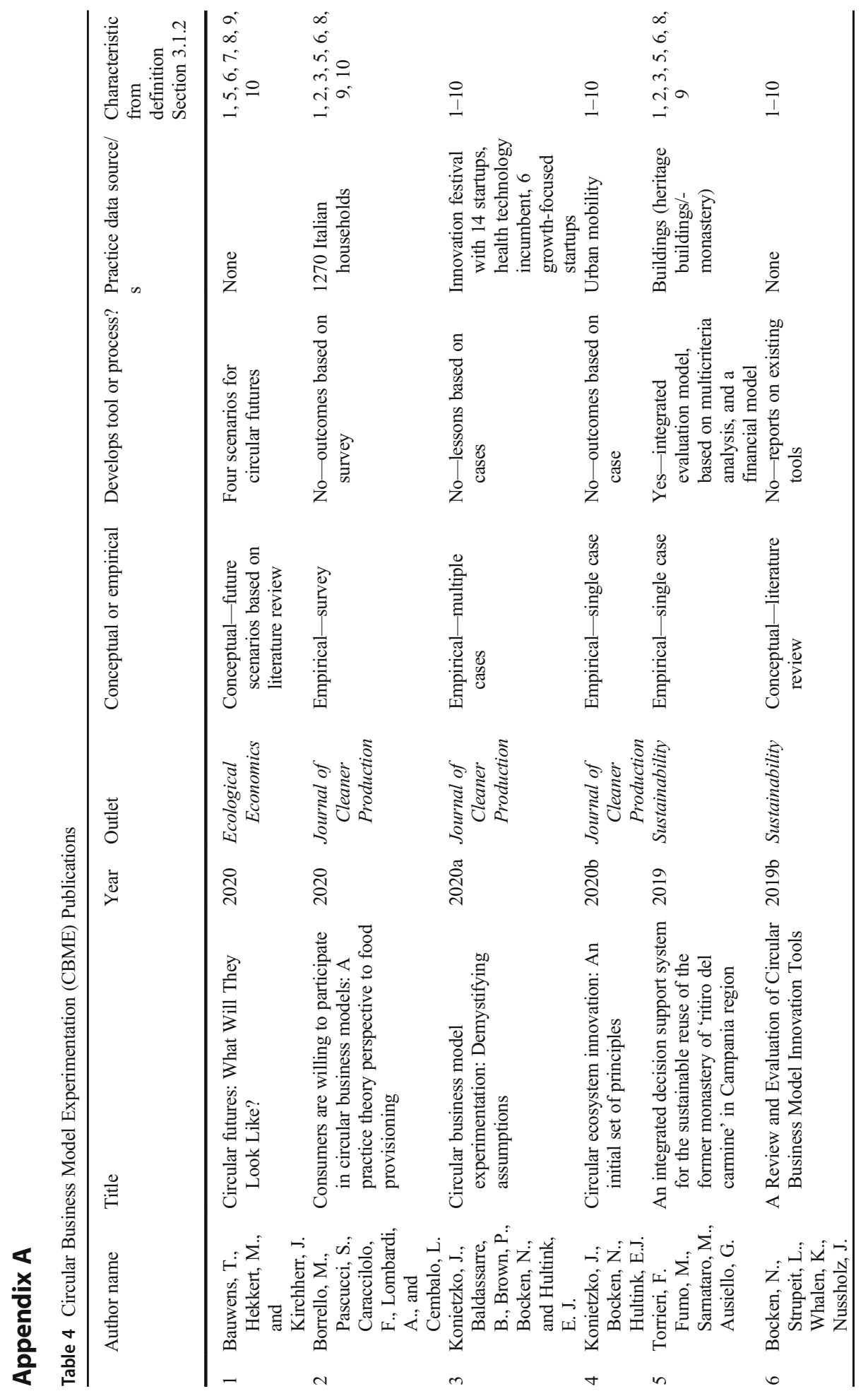




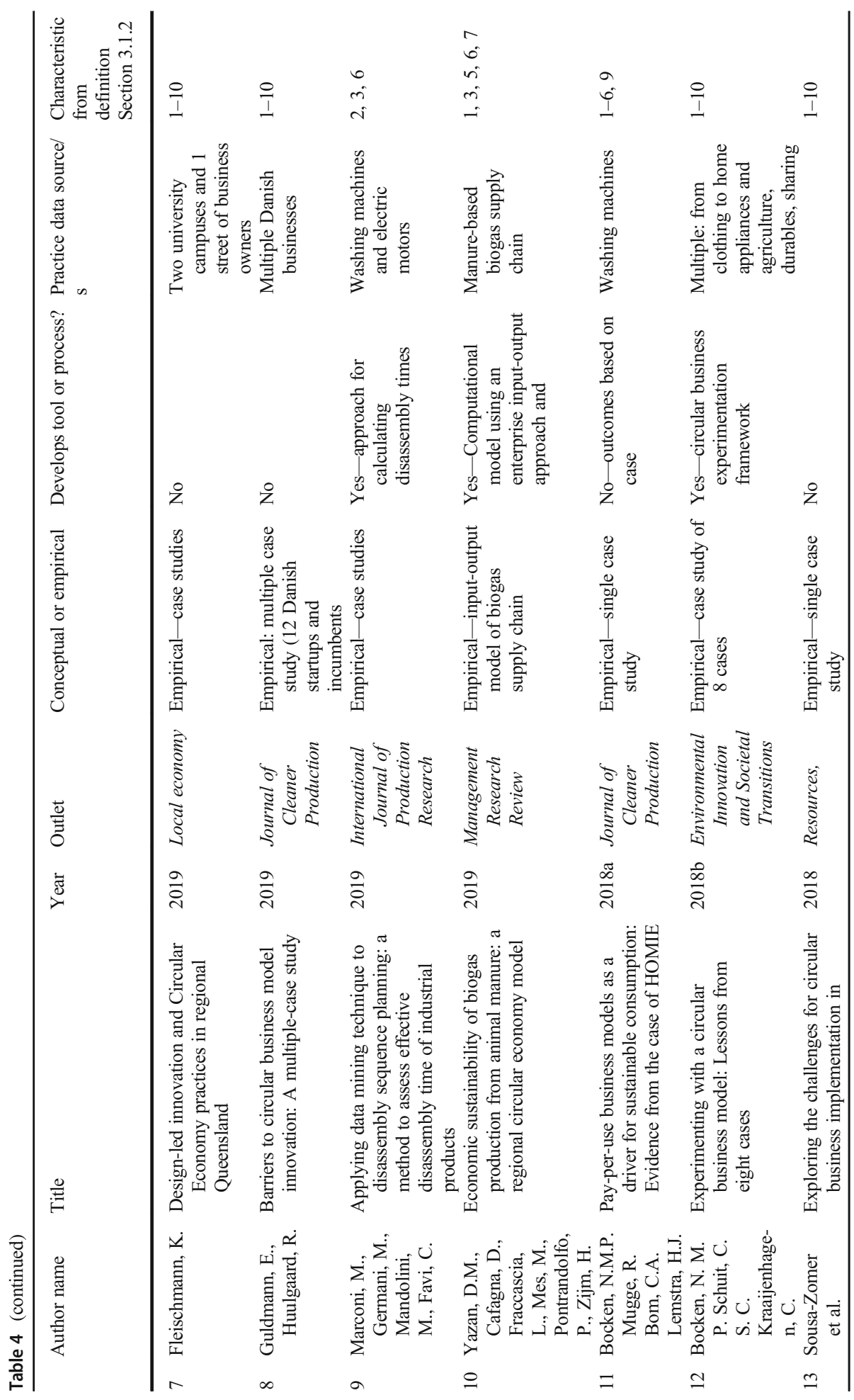




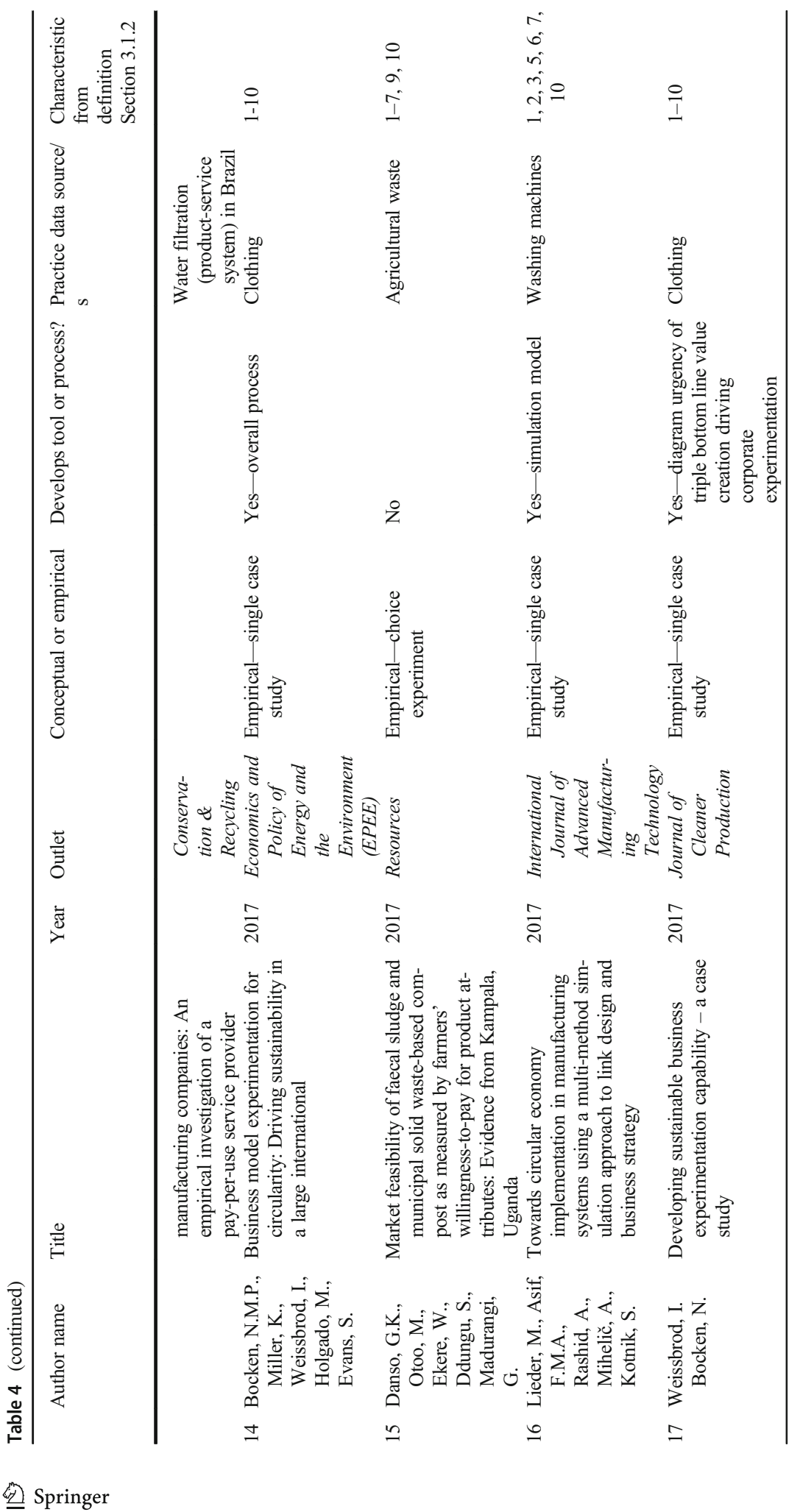




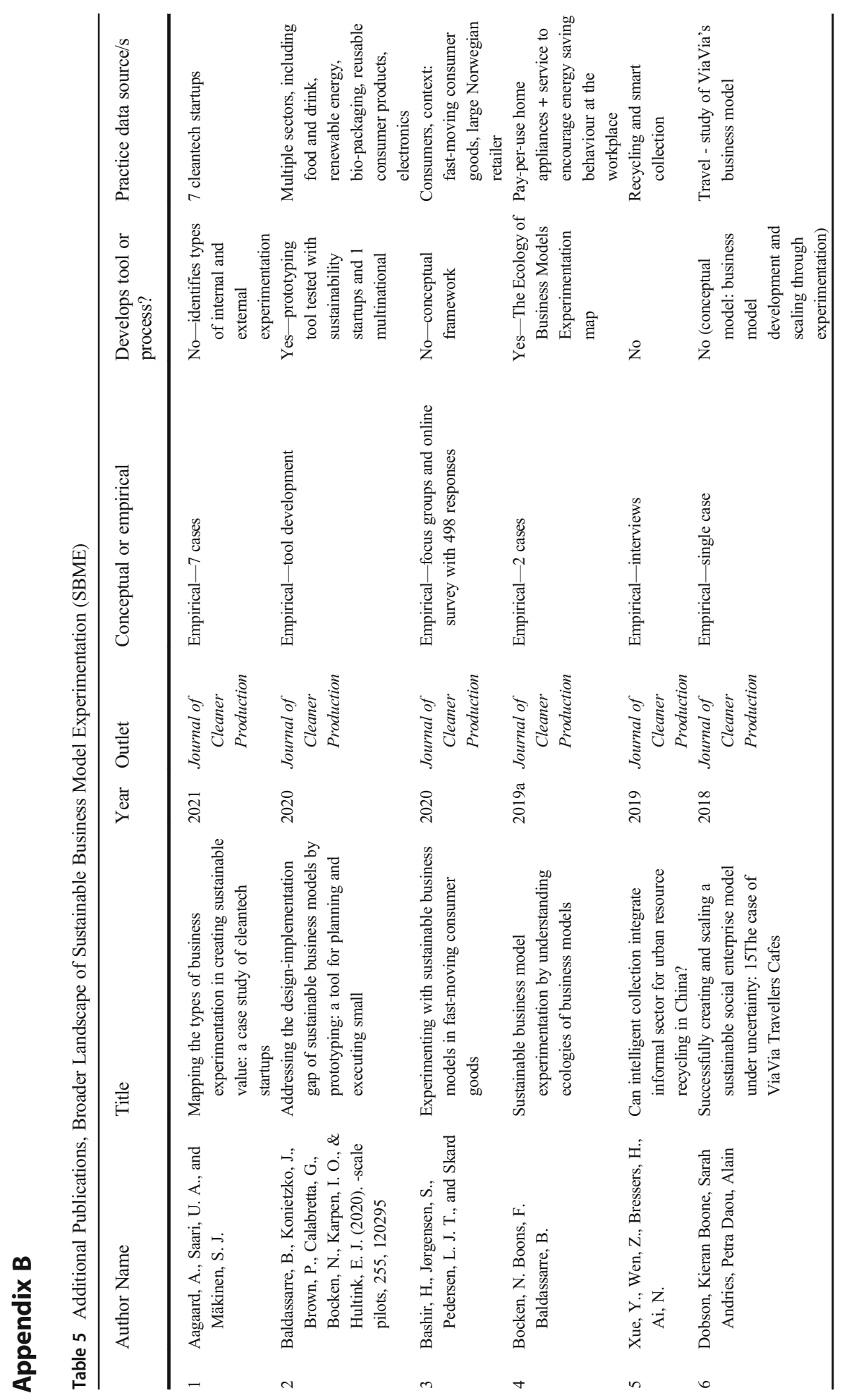




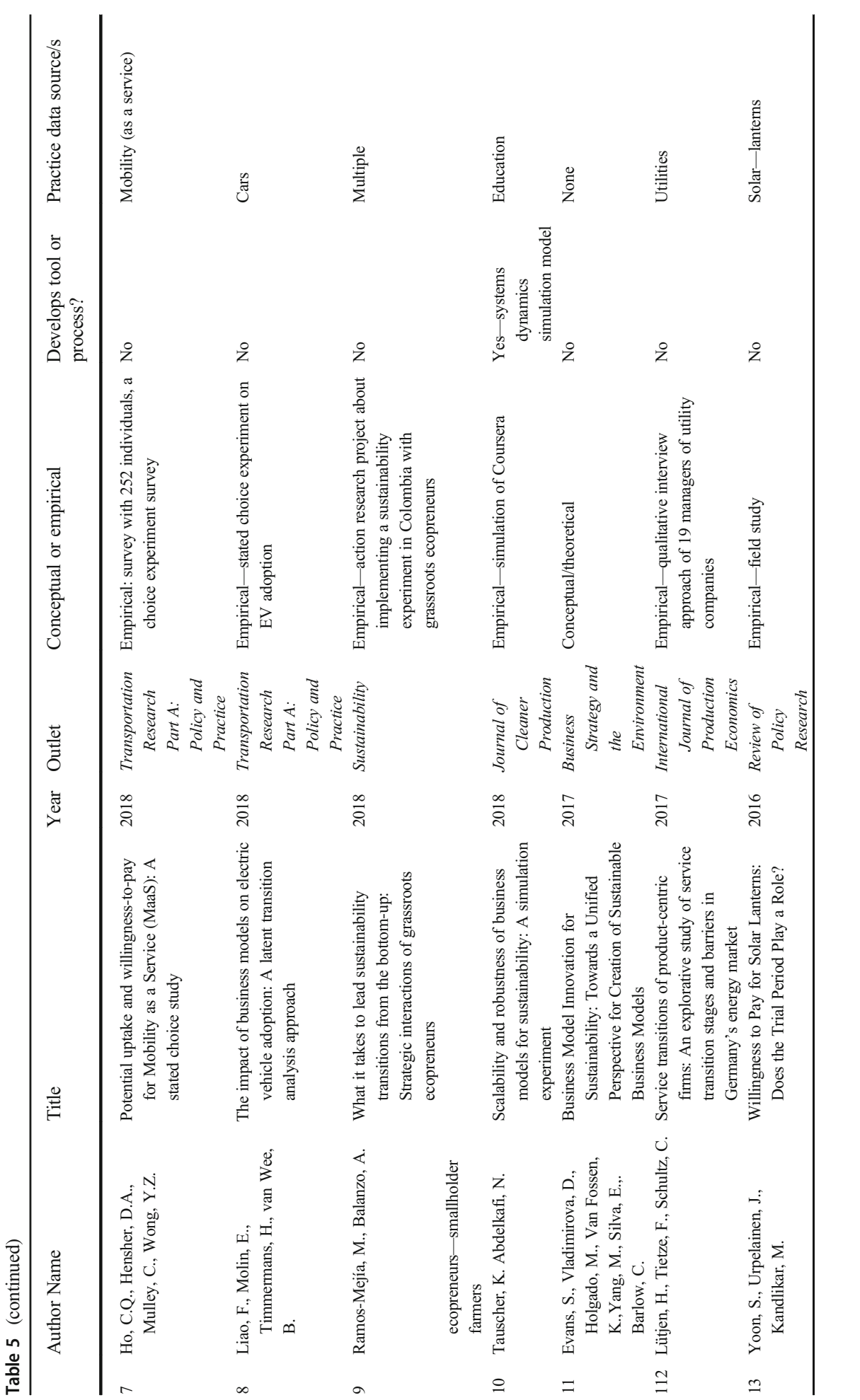




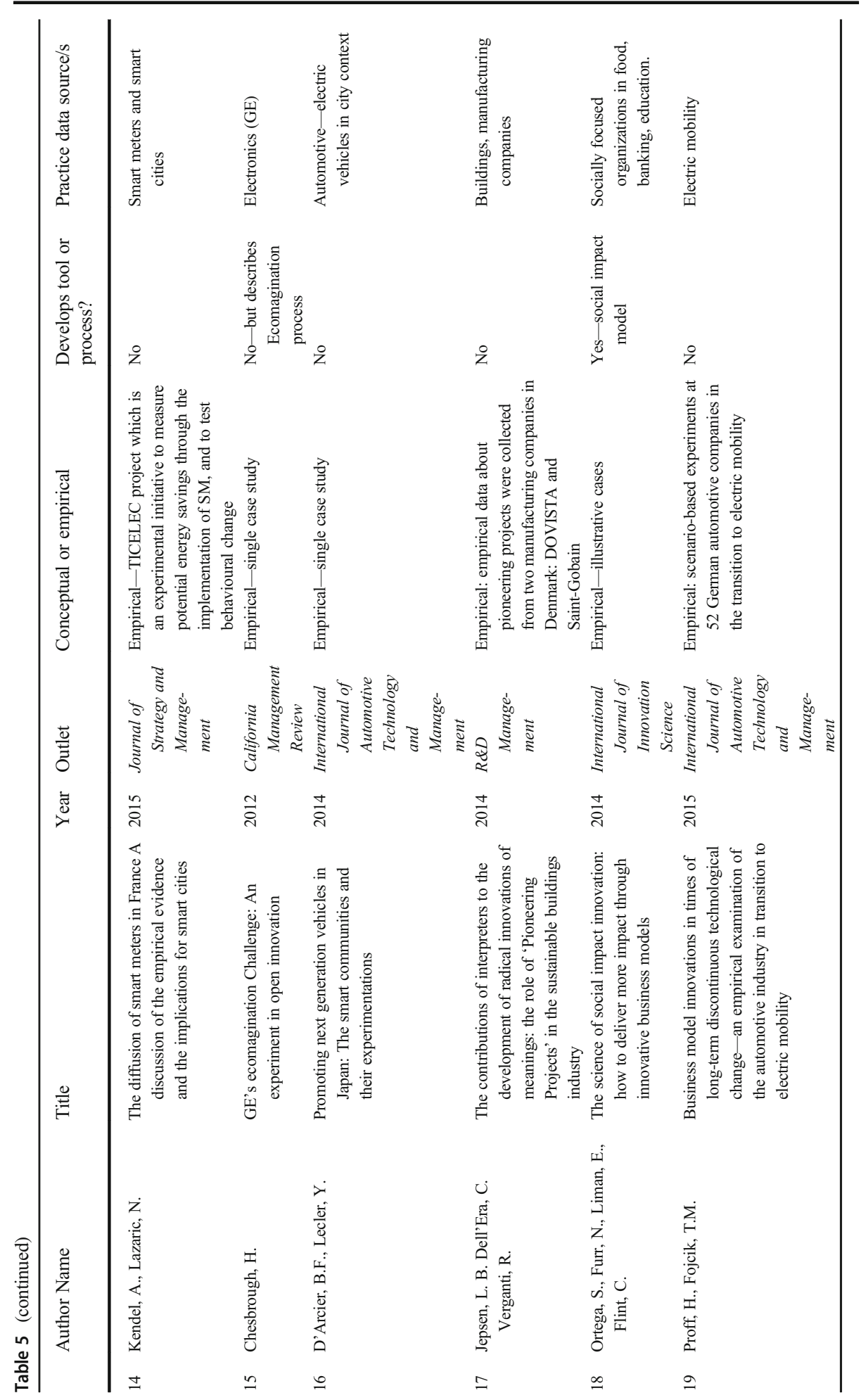




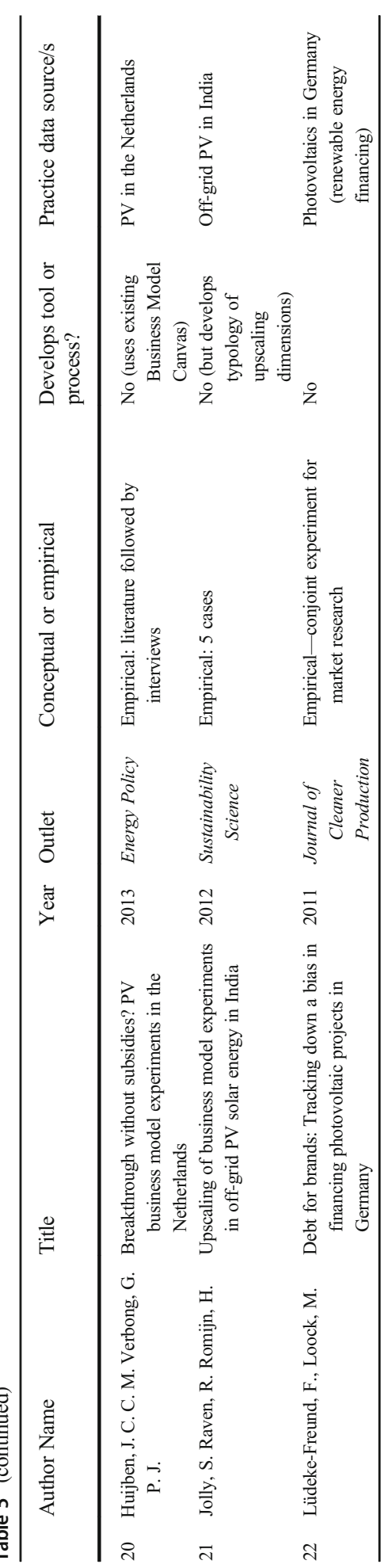

望 Springer 


\section{Appendix C}

Table 6 Definitions from Practitioners Coded According to Criteria

\begin{tabular}{|c|c|c|c|}
\hline & Company and country & Role & Criteria from Section 3.1.2 \\
\hline 1 & $\begin{array}{l}\text { Banking and financial services } \\
\text { organisation A (international) }\end{array}$ & $\begin{array}{l}\text { Sustainability strategy } \\
\text { manager }\end{array}$ & $\begin{array}{l}1,2,4,5,8,9,10 \\
\text { New emphasis: mindset }\end{array}$ \\
\hline 2 & $\begin{array}{l}\text { Banking and financial services } \\
\text { organisation B (international) }\end{array}$ & $\begin{array}{l}\text { Marketing and } \\
\text { sustainability }\end{array}$ & $\begin{array}{l}1,5,8,9,10 \\
\text { New emphasis: consumer focus, } \\
\quad \text { new roles/partnerships }\end{array}$ \\
\hline 3 & $\begin{array}{l}\text { Circular Economy accelerator } \\
\text { (Netherlands) }\end{array}$ & Knowledge lead & $\begin{array}{l}1,2,6,8,10 . \\
\text { New emphasis: lab environment, } \\
\quad \text { scaling up }\end{array}$ \\
\hline 4 & $\begin{array}{l}\text { Coffee retail and non-food products } \\
\text { (Germany) }\end{array}$ & Sustainability manager & $\begin{array}{l}1,10 \\
\text { New emphasis: systemic and } \\
\text { consumer focus }\end{array}$ \\
\hline 5 & Conservation NGO (international) & $\begin{array}{l}\text { Strategic development } \\
\text { advisor }\end{array}$ & $\begin{array}{l}1,4,10 \\
\text { New emphasis: systemic } \\
\quad \text { rethinking }\end{array}$ \\
\hline 6 & Consultancy (UK) & Director & $1,4,5,9$ \\
\hline 7 & $\begin{array}{l}\text { Drink and food supplements } \\
\text { manufacturer (UK) }\end{array}$ & Sustainability manager & $1,2,5$ \\
\hline 8 & Fashion retailer (Finland, International) & Sustainability coordinator & $1,2,5,6,7$ \\
\hline
\end{tabular}

9 Fashion retailer (Multinational)

Innovation lab head

New emphasis: new roles in value chain/partnerships

10 Fashion (Germany)

Sustainability manager

11 Funding Agency for applied research (Belgium)

Circular economy analyst

$1,2,5,10$

$1,5,9,10$

New emphasis: systemic change $1-10$

12 Health and consumer electronics A Venture leader

New emphasis: stakeholder partnerships (multinational)

13 Health and consumer electronics A (multinational)

14 Home appliances, circular economy startup (Netherlands)

15 Innovation consultancy focused on circular economy (Netherlands)

16 Innovation consultancy (Netherlands)

17 Innovation agency (Netherlands)

18 Innovation Fund (Finland)

19 Investment management in early stage startups (Netherlands)

20 Jewellery industry (multinational)

CEO

$1,4,5,6,7,10$

New emphasis: metrics

Startup venture lead

$1,8,10$

Co-founder

$1,3,4,5,10$

Innovation consultant

New emphasis: metrics

$1,4,5,10$

Innovation consultant

$1,5,8,10$.

Business developer

$1,5,6,7,10$

New emphasis: systemic impacts, consumer behaviour

Specialist circular economy $1,2,3,4,5,6,10$

New emphasis: design thinking, role of consumer, policy

$1,2,5$

New emphasis: form hypotheses

Sustainability director

$1-7,9,10$

New emphasis: customer focus, acquisition

21 Manufacturing company (Finland) Sustainability manager

$1,2,5,6,8$

New emphasis: visioning/goals with stakeholders

22 Materials handling company (International)

Development manager

$1,2,5$

New emphasis: scaling up

$1,2,3,4,5,6,10$ 
Table 6 (continued)

\begin{tabular}{|c|c|c|c|}
\hline & Company and country & Role & Criteria from Section 3.1.2 \\
\hline & & $\begin{array}{l}\text { Sustainability innovation } \\
\text { manager }\end{array}$ & \\
\hline \multirow[t]{2}{*}{24} & Strategy consultancy (UK) & Consultant & $1-10$ \\
\hline & & & $\begin{array}{l}\text { New emphasis: systemic impact; } \\
\text { connected stakeholders }\end{array}$ \\
\hline \multirow[t]{2}{*}{25} & Sustainability economy consultancy & Consultant & $1,2,6$ \\
\hline & (UK) & & $\begin{array}{l}\text { New emphasis: established } \\
\text { business context }\end{array}$ \\
\hline 26 & Sustainability non-profit (international) & Principal strategist & $1,4,6,7,9$ \\
\hline 27 & $\begin{array}{l}\text { Textiles SME focused on circular } \\
\text { economy (Denmark) }\end{array}$ & Founder & $\begin{array}{l}1,2,5,6,8,9,10 \\
\text { New emphasis: mindset }\end{array}$ \\
\hline \multirow[t]{2}{*}{28} & Textiles (Finland) & Development manager & $1,2,5,10$ \\
\hline & & & $\begin{array}{l}\text { New emphasis: systemic impact, } \\
\text { consumer }\end{array}$ \\
\hline \multirow[t]{2}{*}{29} & Variety-store chain A & Manager sustainability and & $1,2,4,5,6,7$ \\
\hline & (International) & circular economy & New emphasis: customer, metrics \\
\hline \multirow[t]{2}{*}{30} & Variety-store chain A & Director innovation and & $1,4,5,6,7$ \\
\hline & (International) & sustainability & $\begin{array}{l}\text { New emphasis: } \\
\text { customer/consumer behaviour, } \\
\text { scaling }\end{array}$ \\
\hline
\end{tabular}




$$
I
$$




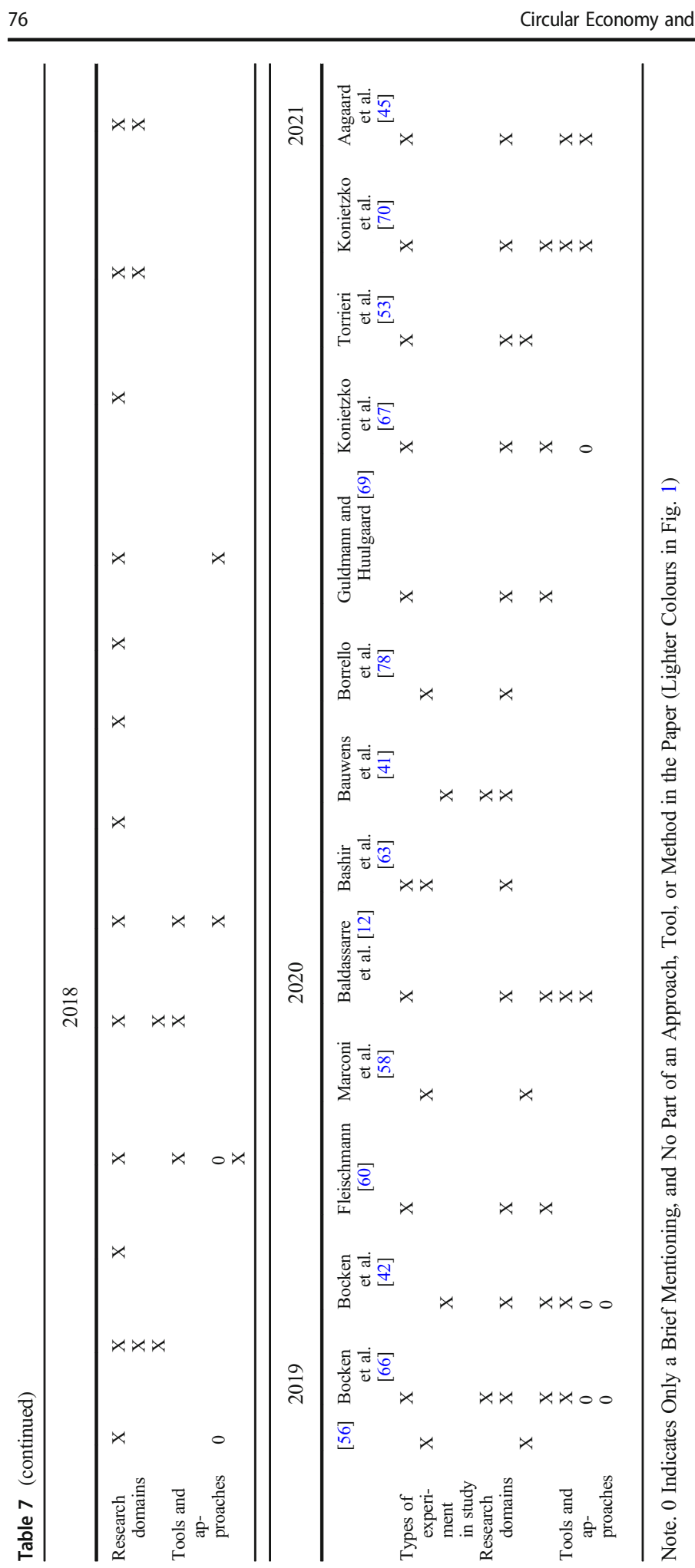

Springer 
Open Access This article is licensed under a Creative Commons Attribution 4.0 International License, which permits use, sharing, adaptation, distribution and reproduction in any medium or format, as long as you give appropriate credit to the original author(s) and the source, provide a link to the Creative Commons licence, and indicate if changes were made. The images or other third party material in this article are included in the article's Creative Commons licence, unless indicated otherwise in a credit line to the material. If material is not included in the article's Creative Commons licence and your intended use is not permitted by statutory regulation or exceeds the permitted use, you will need to obtain permission directly from the copyright holder. To view a copy of this licence, visit http://creativecommons.org/licenses/by/4.0/.

\section{References}

** indicates that the paper is part of the CBME literature review selection; * indicates that it is part of the broader SBME review selection

1. Kalmykova Y, Sadagopan M, Rosado L (2018) Circular economy-from review of theories and practices to development of implementation tools. Resour Conserv Recycl 135:190-201

2. Kirchherr J, Reike D, Hekkert M (2017) Conceptualizing the circular economy: an analysis of 114 definitions. Resour Conserv Recycl 127:221-232

3. Bocken, N.M.P., de Pauw, I., van der Grinten, B., \& Bakker, C. (2016). Product design and business model strategies for a circular economy. J Ind Prod Eng, 32 (1), 67-81. https://doi.org/10.1080/21681015. 2016.1172124

4. Bocken NMP, Stahel W, Dobrauz G, Koumbarakis A, Obst M, Matzdorf P (2021) Circularity as the new normal. Future fitting Swiss business strategies. WWF Switzerland and PWC

5. Geissdoerfer M, Savaget P, Bocken N, Hultink E (2017) The circular economy - a new sustainability paradigm? J Clean Prod 143:757-768. https://doi.org/10.1016/j.jclepro.2016.12.048

6. World Economic Forum (2018) The view from Davos: how to accelerate action on the circular economy. Available at: https://www.weforum.org/agenda/2018/02/shaping-a-shared-future-accelerating-action-for-acircular-economy/ (accessed 2 April 2020)

7. Blomsma F, Pieroni M, Kravchenko M, Pigosso D, Hildenbrand J, Kristinsdottir AR, Kristoffersen E, Shabazi S, Nielsen KD, Jönbrink A-R, Li J, Wiik C, McAloone TC (2019) Developing a circular strategies framework for manufacturing companies to support circular economy oriented innovation. J Clean Prod 241:118271. https://doi.org/10.1016/j.jclepro.2019.118271

8. Fischer A, Pascucci S (2017) Institutional incentives in circular economy transition: the case of material use in the Dutch textile industry. J Clean Prod 155:17-32. https://doi.org/10.1016/j.jclepro.2016.12.038

9. Ritala P, Huotari P, Bocken N, Albareda L, Puumalainen K (2018) Sustainable business model adoption among S\&P 500 firms: A longitudinal content analysis study. J Clean Prod 170:216-226. https://doi.org/ 10.1016/j.jclepro.2017.09.159

10. Linder M, Williander M (2017) Circular business model innovation: inherent uncertainties. Bus Strateg Environ 26(2):182-196. https://doi.org/10.1002/bse.1906

11. Blomsma F, Brennan G (2017) The emergence of circular economy: a new framing around prolonging resource productivity. J Ind Ecol 21(3):603-614. https://doi.org/10.1111/jiec.12603

12. * Baldassarre B, Konietzko J, Brown P, Calabretta G, Bocken N, Karpen IO, Hultink EJ (2020) Addressing the design-implementation gap of sustainable business models by prototyping: A tool for planning and executing small-scale pilots. J Clean Prod 255:120295. https://doi.org/10.1016/j.jclepro. 2020.120295

13. IPCC (2018) Summary for Policymakers. In: Masson-Delmotte V, Zhai P, Pörtner DHO et al (eds) Global warming of $1.5^{\circ} \mathrm{C}$. An IPCC Special Report on the impacts of global warming of $1.5^{\circ} \mathrm{C}$ above preindustrial levels and related global greenhouse gas emission pathways, in the context of strengthening the global response to the threat of climate change, sustainable development, and efforts to eradicate poverty. World Meteorological Organization, Geneva, Switzerland $32 \mathrm{pp}$

14. Steffen W, Broadgate W, Deutsch L, Gaffney O, Ludwig C (2015) The trajectory of the Anthropocene: the Great Acceleration. Stock Resil Cent:81-98

15. PACE (Platform for Accelerating the Circular Economy) (2020) About. Available at: https://pacecircular. org/about (accessed 11 March 2020) 
16. ** Bocken NM, Mugge R, Bom CA, Lemstra HJ (2018a) Pay-per-use business models as a driver for sustainable consumption: evidence from the case of HOMIE. J Cleaner Prod, 198, 498-510. https://doi.org/ 10.1016/j.jclepro.2018.07.043

17. ** Bocken NMP; Schuit CSC, Kraaijenhagen C (2018b) Experimenting with a circular business model: lessons from eight cases. Environ Innov Soc Transit, 28, 79-95. https://doi.org/10.1016/j.eist.2018.02.001

18. Adams R, Jeanrenaud S, Bessant J, Denyer D, Overy P (2016) Sustainability-oriented innovation: a systematic review. Int J Manag Rev 18(2):180-205. https://doi.org/10.1111/ijmr.12068

19. Hart SL, Milstein MB (2003) Creating sustainable value. Acad Manag Perspect 17(2):56-67. https://doi. org/10.5465/ame.2003.10025194

20. Chesbrough H (2010) Business model innovation: opportunities and barriers. Long Range Plan 43(2):354 363. https://doi.org/10.1016/j.lrp.2009.07.010

21. Sengers F, Wieczorek AJ, Raven R (2019) Experimenting for sustainability transitions: a systematic literature review. Technol Forecast Soc Chang 145:153-164. https://doi.org/10.1016/j.techfore.2016.08. 031

22. ** Weissbrod I, Bocken N (2017) Developing sustainable business experimentation capability - a case study. J Cleaner Prod, 142 (4), 2663-2676. https://doi.org/10.1016/j.jclepro.2016.11.009

23. Jørgensen S, Pedersen LJT (2018) RESTART sustainable business model innovation. Springer. https://doi. org/10.1007/978-3-319-91971-3

24. Kraaijenhagen C, Van Oppen C, Bocken N (2016) Circular business. Collaborate \& Circulate. Circular Collaboration, Amersfoort, The Netherlands circularcollaboration.com

25. Sarasini S, Linder M (2017) Integrating a business model perspective into transition theory: the example of new mobility services. Environ Innov Soc Transit 27:16-31. https://doi.org/10.1016/j.eist.2017.09.004

26. Kemp R, Schot J, Hoogma R (1998) Regime shifts to sustainability through processes of niche formation: the approach of strategic niche management. Tech Anal Strat Manag 10(2):175-198. https://doi.org/10. $1080 / 09537329808524310$

27. Schot J, Geels FW (2008) Strategic niche management and sustainable innovation journeys: theory, findings, research agenda, and policy. Tech Anal Strat Manag 20(5):537-554. https://doi.org/10.1080/ 09537320802292651

28. Luederitz C, Schäpke N, Wiek A, Lang DJ, Bergmann M, Bos JJ, Burch S, Davies A, Evans J, König A, Farrelly MA, Forrest N, Frantzeskaki N, Gibson RB, Kay B, Loorbach D, McCormick K, Parodi O, Rauschmayer F, Schneidewind U, Stauffacher M, Stelzer F, Trencher G, Venjakob J, Vergragt PJ, von Wehrden H, Westley FR (2017) Learning through evaluation - a tentative evaluative scheme for sustainability transition experiments. J Clean Prod 169:61-76. https://doi.org/10.1016/j.jclepro.2016.09. 005

29. Caniglia G, Schäpke N, Lang DJ, Abson DJ, Luederitz C, Wiek A, Laubichler MD, Gralla F, von Wehrden H (2017) Experiments and evidence in sustainability science: a typology. J Clean Prod 169: 39-47. https://doi.org/10.1016/j.jclepro.2017.05.164

30. Weissbrod I (2019) Experimentation for sustainable innovation. In: Bocken N, Ritala P, Albareda L, Verburg R (eds) Innovation for Sustainability. Palgrave Studies in Sustainable Business in Association with Future Earth. Palgrave Macmillan, pp 335-352. https://doi.org/10.1007/978-3-319-97385-2_18

31. Andries, P., Debackere, K., \& Van Looy, B. (2013). Simultaneous experimentation as a learning strategy: business model development under uncertainty. Strateg Entrep J, 7, 288-310. https://doi.org/10.1002/sej. 1170

32. Bojovic N, Genet C, Sabatier V (2018) Learning, signaling, and convincing: the role of experimentation in the business modeling process. Long Range Plan 51(1):141-157. https://doi.org/10.1016/j.lrp.2017.09.001

33. Bojovic N, Sabatier V, Coblence E (2019) Becoming through doing: how experimental spaces enable organizational identity work. Strateg Organ:1-30. https://doi.org/10.1177/1476127019864673

34. Felin T, Gambardella A, Stern S, Zenger T (2020) Lean startup and the business model: experimentation revisited. Long Range Plan 101889. https://doi.org/10.1016/j.lrp.2019.06.002

35. Osterwalder A, Pigneur Y, Bernarda G, Smith A (2014) Value proposition design: how to create products and services customers want. John Wiley \& Sons, New Jersey

36. Ries E (2011) The lean startup. Penguin Books, London

37. Keskin D (2015) Product innovation in sustainability-oriented new ventures. Doctoral thesis. TU Delft, Industrial Design Engineering, Netherlands

38. Sarasvathy S (2001) Causation and effectuation: toward a theoretical shift from economic inevitability to entrepreneurial contingency. Acad Manag Rev 26(2):243-263. https://doi.org/10.5465/amr.2001.4378020

39. Zollo M, Cennamo C, Neumann K (2013) Beyond what and why: understanding organizational evolution towards sustainable enterprise models. Organ Environ 26(3):241-259. https://doi.org/10.1177/ 1086026613496433

40. Bryman A, Bell E (2015) Business research methods. Oxford University Press, USA 
41. ** Bauwens T, Hekkert M, Kirchherr J (2020). Circular futures: what will they look like? Ecol Econ, 175, 106703. https://doi.org/10.1016/j.ecolecon.2020.106703

42. ** Bocken N, Strupeit L, Whalen K, Nußholz J (2019b) A review and evaluation of circular business model innovation tools. Sustainability, 11(8), 2210. https://doi.org/10.3390/su11082210

43. * Evans, S., Vladimirova, D., Holgado, M., Van Fossen, K., Yang, M., Silva, E., \& Barlow, C. (2017). Business model innovation for sustainability: towards a unified perspective for creation of sustainable business models. Bus Strateg Environ, 26(5), 597-608. https://doi.org/10.1002/bse.1939

44. * Ramos-Mejía M, Balanzo A (2018) What it takes to lead sustainability transitions from the bottom-up: strategic interactions of grassroots ecopreneurs. Sustainability 10(7):2294. https://doi.org/10.3390/ su10072294

45. ** Aagaard A, Saari UA, Mäkinen SJ (2021). Mapping the types of business experimentation in creating sustainable value: a case study of cleantech start-ups. J Cleaner Prod, 123182.

46. * Ortega S, Furr N, Liman E, Flint C (2014) The science of social impact innovation: how to deliver more impact through innovative business models. Int J Innov Sci 6(2):73-82. https://doi.org/10.1260/17572223.6.2.73

47. * d'Arcier B, Lecler Y (2014) Promoting next generation vehicles in Japan: the smart communities and their experimentations. Int J Automot Technol Manag 14(3/4):324-346. https://doi.org/10.1504/IJATM. 2014.065296

48. * Ho CQ, Hensher DA, Mulley C, Wong YZ (2018) Potential uptake and willingness-to-pay for Mobility as a Service (MaaS): A stated choice study. Transp Res A Policy Pract 117:302-318. https://doi.org/10. 1016/j.tra.2018.08.025

49. * Lüdeke-Freund F, Loock M (2011) Debt for brands: tracking down a bias in financing photovoltaic projects in Germany. J Clean Prod 19(12):1356-1364. https://doi.org/10.1016/j.jclepro.2011.04.006

50. * Kendel A, Lazaric N (2015) The diffusion of smart meters in France: a discussion of the empirical evidence and the implications for smart cities. J Strateg Manag 8(3):231-244

51. * Xue Y, Wen Z, Bressers H, Ai N (2019) Can intelligent collection integrate informal sector for urban resource recycling in China? J Clean Prod 208:307-315. https://doi.org/10.1016/j.jclepro.2018.10.155

52. * Jepsen LB, Dell'Era C, Verganti R (2014) The contributions of interpreters to the development of radical innovations of meanings: the role of 'Pioneering Projects' in the sustainable buildings industry. R\&D Manag 44(1):1-17. https://doi.org/10.1111/radm.12035

53. ** Torrieri F, Fumo M, Sarnataro M, Ausiello G (2019) An integrated decision support system for the sustainable reuse of the former monastery of "Ritiro del Carmine" in Campania Region. Sustainability, 11(19), 5244. https://doi.org/10.3390/su11195244

54. ** Bocken NMP, Miller K, Weissbrod I, Holgado M, Evans S (2017) Business model experimentation for circularity: sustainability in a large international clothing retailer. Econ Policy Energy Environ 1-2 / 2017, 85-122. https://doi.org/10.3280/EFE2017-001006

55. ** Danso GK, Otoo M, Ekere W, Ddungu S, Madurangi G (2017) Market feasibility of faecal sludge and municipal solid waste-based compost as measured by farmers' willingness-to-pay for product attributes: evidence from Kampala, Uganda. Resources, 6(3), 31. https://doi.org/10.3390/resources6030031

56. ** Yazan DM, Cafagna D, Fraccascia L, Mes M, Pontrandolfo P, Zijm H (2018) Economic sustainability of biogas production from animal manure: a regional circular economy model. Manag Res Rev, 41 (5), 605-624. https://doi.org/10.1108/MRR-02-2018-0053

57. ** Lieder M, Asif FM, Rashid A, Mihelič A, Kotnik S (2017) Towards circular economy implementation in manufacturing systems using a multi-method simulation approach to link design and business strategy. Int J Adv Manuf Technol, 93(5-8), 1953-1970. https://oi.org/10.1007/s00170-017-0610-9

58. ** Marconi M, Germani M, Mandolini M, Favi C (2019). Applying data mining technique to disassembly sequence planning: a method to assess effective disassembly time of industrial products. Int J Prod Res, 57(2), 599-623. https://doi.org/10.1080/00207543.2018.1472404

59. * Täuscher K, Abdelkafi N (2018) Scalability and robustness of business models for sustainability: a simulation experiment. J Clean Prod 170:654-664. https://doi.org/10.1016/j.jclepro.2017.09.023

60. ** Fleischmann K (2019) Design-led innovation and circular economy practices in regional Queensland. Local Econ, 34(4), 382-402. https://doi.org/10.1177/0269094219854679

61. * Dobson K, Boone S, Andries P, Daou A (2018) Successfully creating and scaling a sustainable social enterprise model under uncertainty: the case of ViaVia Travellers Cafés. J Clean Prod 172:4555-4564. https://doi.org/10.1016/j.jclepro.2017.09.010

62. ** Sousa-Zomer TT, Magalhães L, Zancul E, Cauchick-Miguel PA (2018) Exploring the challenges for circular business implementation in manufacturing companies: an empirical investigation of a pay-per-use service provider. Resour Conserv Recycl, 135, 3-13. https://doi.org/10.1016/j.resconrec.2017.10.033

63. * Bashir H, Jørgensen S, Pedersen LJT, Skard S (2020) Experimenting with sustainable business models in fast moving consumer goods. J Clean Prod 122302. https://doi.org/10.1016/j.jclepro.2020.122302 
64. Blank S (2013a) The four steps to the epiphany: successful strategies for products That Win. K\&S Ranch Publishing, San Francisco, USA

65. Tukker A (2004) Eight types of product-service system: eight ways to sustainability? Experiences from SusProNet. Bus Strateg Environ 13(4):246-260. https://doi.org/10.1002/bse.414

66. * Bocken N, Boons F, Baldassarre B (2019a) Sustainable business model experimentation by understanding ecologies of business models. J Clean Prod 208:1498-1512. https://doi.org/10.1016/j.jclepro.2018.10. 159

67. ** Konietzko J, Bocken N, Hultink EJ (2020b) Circular ecosystem innovation: an initial set of principles. J Clean Prod, 253, 119942. https://doi.org/10.1016/j.jclepro.2019.119942

68. Tukker A (2015) Product services for a resource-efficient and circular economy-a review. J Clean Prod 97: 76-91. https://doi.org/10.1016/j.jclepro.2013.11.049

69. ** Guldmann E, Huulgaard RD (2020) Barriers to circular business model innovation: a multiple-case study. J Cleaner Prod, 243, 118160. https://doi.org/10.1016/j.jclepro.2019.118160

70. ** Konietzko J, Baldassarre B, Brown P, Bocken N, Hultink EJ (2020a) Circular business model experimentation: demystifying assumptions. J Clean Prod, 122596.

71. * Huijben JC, Verbong GP (2013) Breakthrough without subsidies? PV business model experiments in the Netherlands. Energy Policy 56:362-370. https://doi.org/10.1016/j.enpol.2012.12.073

72. * Chesbrough H (2012) GE's ecomagination challenge: an experiment in open innovation. Calif Manag Rev 54(3):140-154. https://doi.org/10.1525/cmr.2012.54.3.140

73. * Jolly S, Raven R, Romijn H (2012) Upscaling of business model experiments in off-grid PV solar energy in India. Sustain Sci 7(2):199-212. https://doi.org/10.1007/s11625-012-0163-7

74. * Proff H, Fojcik TM (2015) Business model innovations in times of long-term discontinuous technological change-an empirical examination of the automotive industry in transition to electric mobility. Int $\mathbf{J}$ Automot Technol Manag 15(4):418-442. https://doi.org/10.1504/IJATM.2015.072880

75. * Yoon S, Urpelainen J, Kandlikar M (2016) Willingness to pay for solar lanterns: does the trial period play a role? Rev Policy Res 33(3):291-315. https://doi.org/10.1111/ropr.12174

76. * Lütjen H, Tietze F, Schultz C (2017) Service transitions of product-centric firms: an explorative study of service transition stages and barriers in Germany's energy market. Int J Prod Econ 192:106-119. https:// doi.org/10.1016/j.ijpe.2017.03.021

77. * Liao, F., Molin, E., Timmermans, H., \& van Wee, B. (2018). The impact of business models on electric vehicle adoption: a latent transition analysis approach. Transp Res A Policy Pract, 116, 531-546. https:// doi.org/10.1016/j.tra.2018.07.008

78. ** Borrello M, Pascucci S, Caracciolo F, Lombardi A, Cembalo L (2020) Consumers are willing to participate in circular business models: a practice theory perspective to food provisioning. J Cleaner Prod, 259, 121013. https://doi.org/10.1016/j.jclepro.2020.121013

79. Camuffo A, Cordova A, Gambardella A. (2017) A scientific approach to entrepreneurial experimentation: evidence from a randomized control trial. Working Paper. 1-34

80. Blank S (2013b) Why the lean start-up changes everything. Harv Bus Rev

81. Pieroni MP, McAloone T, Pigosso DA (2019) Business model innovation for circular economy and sustainability: a review of approaches. J Clean Prod 215:198-216. https://doi.org/10.1016/j.jclepro.2019. 01.036

82. Geels F (2005) Technological transitions and system innovations: a co-evolutionary and socio-technical analysis, first edn. Edward Elgar Publishing Limited, Inc, Cheltenham

83. Geels FW (2011) The multi-level perspective on sustainability transitions: responses to seven criticisms. Environ Innov Soc Transit 1(1):24 40. https://doi.org/10.1016/j.eist.2011.02.002

84. Geels F, Raven R (2006) Non-linearity and expectations in niche-development trajectories: ups and downs in Dutch biogas development (1973-2003). Tech Anal Strat Manag 18:375-392. https://doi.org/10.1080/ 09537320600777143

85. Smith A, Raven R (2012) What is protective space? Reconsidering niches in transitions to sustainability. Res Policy 41(6):1025-1036. https://doi.org/10.1016/j.respol.2011.12.012

86. Osterwalder A, Pigneur Y (2010) Business model generation: a handbook for visionaries, game changers, and challengers. Wiley, Hoboken, NJ

87. Bocken N, Short S (2016) Towards a sufficiency-driven business model: Experiences and opportunities. Environ Innov Soc Transit 18:(41-61)

88. Voros J (2003) A generic foresight process framework. Foresight 5(3):10-21. https://doi.org/10.1108/ 14636680310698379

89. Cembalo L, Lombardi A, Pascucci S, Dentoni D, Migliore G, Verneau F, Schifani G (2015) "Rationally local": consumer participation in alternative food chains. Agribusiness 31(3):330-352. https://doi.org/10. 1002/agr.21419 
90. Yazan DM, Garavelli AC, Messeni Petruzzelli A, Albino V (2011) The effect of spatial variables on the economic and environmental performance of bioenergy production chains. Int J Prod Econ 131(1):224 233. https://doi.org/10.1016/j.ijpe.2010.07.017

91. Davis JP, Eisenhardt KM, Bingham CB (2007) Developing theory through simulation methods. Acad Manag Rev 32:480-499. https://doi.org/10.5465/amr.2007.24351453

92. Takakuwa S (1997) The use of simulation in activity-based costing for flexible manufacturing systems. In: Proceedings of the 1997 Winter Simulation Conference, pp 793-800. https://doi.org/10.1145/268437. 268657

93. Cooper RG (1990) Stage-gate systems: a new tool for managing new products. Bus Horiz 33(3):44-54. https://doi.org/10.1016/0007-6813(90)90040-I

94. Elkington J (1997) Cannibals with Forks: the triple bottom line of 21 st century business. Capstone, Oxford

95. Brown T, Wyatt J (2010) Design thinking for social innovation. Stanford Social Innovation Review. 30-37 $<$ last accessed 4-27-2014, http://www.ssireview.org/images/articles/2010WI_Features_WyattBrown New.pdf $>$

96. Prendeville S, Bocken N (2017) Sustainable business models through service design. Procedia Manuf 8: 292-299

97. Shostack GL (1982) How to Design a Service. Eur J Mark 16(1):49-63. https://doi.org/10.1108/ EUM0000000004799

98. Whalen KA, Berlin C, Ekberg J, Barletta I, Hammersberg P (2018) 'All they do is win': Lessons learned from use of a serious game for Circular Economy education. Resour Conserv Recycl 135:335-345. https:// doi.org/10.1016/j.resconrec.2017.06.021

99. Frosch RA, Gallopoulos NE (1989) Strategies for manufacturing. Sci Am:144-152

100. Delmas MA, Aragon-Correa JA (2016) Field experiments in corporate sustainability research: testing strategies for behavior change in markets and organizations. Organ Environ Editorial. https://doi.org/10. $1177 / 1086026616677827$

101. Antikainen M, Aminoff A, Paloheimo H, Kettunen O (2017) Designing circular business model experimentation-case study. In: ISPIM Innovation Symposium. The International Society for Professional Innovation Management (ISPIM)

102. Snihur Y, Wiklund J (2019) Searching for innovation: Product, process, and business model innovations and search behavior in established firms. Long Range Plan 52(3):305-325. https://doi.org/10.1016/j.lrp. 2018.05.003

103. Laasch O (2019) An actor-network perspective on business models: how 'being responsible' led to incremental but pervasive change. Long Range Plan 52(3):406-426. https://doi.org/10.1016/j.lrp.2018. 04.002

104. Teece DJ (2018) Business models and dynamic capabilities. Long Range Plan 51(1):40-49. https://doi.org/ 10.1016/j.lrp.2017.06.007

105. Bocken N, Snihur Y (2020) Lean Startup and the business model: experimenting for novelty and impact. Long Range Plan 53(4):101953

106. Ries E (2017) The startup way. Penguin Random House UK, Milton Keynes UK 